University of Nebraska - Lincoln

DigitalCommons@University of Nebraska - Lincoln

Faculty Publications from the Harold W. Manter Laboratory of Parasitology

$10-2007$

\title{
Geographic and Host Range of the Nematode Soboliphyme baturini across Beringia
}

\author{
Anson V.A. Koehler \\ University of New Mexico, ansonkoehler@gmail.com \\ Eric P. Hoberg \\ United States Department of Agriculture, eric.hoberg@ars.usda.gov \\ Nikolai E. Dokuchaev \\ Far Eastern Branch of the Russian Academy of Sciences \\ Joseph A. Cook \\ University of New Mexico
}

Follow this and additional works at: https://digitalcommons.unl.edu/parasitologyfacpubs

Part of the Parasitology Commons

Koehler, Anson V.A.; Hoberg, Eric P.; Dokuchaev, Nikolai E.; and Cook, Joseph A., "Geographic and Host Range of the Nematode Soboliphyme baturini across Beringia" (2007). Faculty Publications from the Harold W. Manter Laboratory of Parasitology. 330.

https://digitalcommons.unl.edu/parasitologyfacpubs/330

This Article is brought to you for free and open access by the Parasitology, Harold W. Manter Laboratory of at DigitalCommons@University of Nebraska - Lincoln. It has been accepted for inclusion in Faculty Publications from the Harold W. Manter Laboratory of Parasitology by an authorized administrator of DigitalCommons@University of Nebraska - Lincoln. 


\title{
GEOGRAPHIC AND HOST RANGE OF THE NEMATODE SOBOLIPHYME BATURINI ACROSS BERINGIA
}

\author{
Anson V. A. Koehler, Eric P. Hoberg ${ }^{\star}$, Nikolai E. Dokuchaev $\dagger$, and Joseph A. Cook \\ Department of Biology, University of New Mexico, Albuquerque, New Mexico 87131.e-mail: ansonkoehler@gmail.com
}

\begin{abstract}
The nematode Soboliphyme baturini Petrov, 1930, was found to represent a single species with a relatively broad geographic range across Beringia and northwestern North America on the basis of the assessment of molecular sequence data for adult and juvenile parasites. Refuted are hypotheses suggesting that several cryptic species could be partitioned either among an array of mustelid definitive hosts or across the vast region that links North America and Eurasia. Host specificity for this species is examined on the basis of a comprehensive list for definitive hosts, derived from new field surveys and existing literature for S. baturini. Only 5 mustelids (Gulo gulo, Martes americana, M. caurina, M. zibellina, and Neovison vison) appear to have significant roles in the life history, persistence, and transmission of this nematode. Soboliphyme baturini readily switches among M. americana, M. caurina, Mustela erminea, or $N$. vison at any particular locality throughout its geographic range in North America, although Martes spp. could represent the source for nematodes in a broader array of mustelids. Molecular analyses (243 base pairs of mitochondrial gene nicotinamide dehydrogenase [ND4]) suggest that hypotheses for host specificity across an array of mustelid definitive hosts are not supported. The life cycle of $S$. baturini is explored through a review of diet literature for 2 marten species, M. americana and M. caurina, and other mustelids across the Holarctic. Shrews (Soricomorpha: Soricidae) comprise $>8 \%$ of prey for these species of Martes, suggesting their putative role as paratenic hosts. Juvenile nematodes found in the diaphragms of soricids are genetically identical to adult $S$. baturini found in the stomachs of mustelids at the same locations in both Asia and North America, corroborating a role in transmission for species of Sorex.
\end{abstract}

Establishing the roles for each participant in a parasite's life cycle is essential to interpreting ecology, epidemiology, distribution, and phylogeographic history. Hosts that are components of the life cycle can be defined as definitive (parasite achieves sexual maturity), intermediate (parasite develops, but does not reach sexual maturity), and paratenic (parasite undergoes no development stages, but might be transported from one trophic level to another) (Roberts and Janovy, 2005). Hosts can also be defined as incidental, when the parasite fails to reach sexual maturity. In this case, the host is unnecessary to the parasite life cycle and, therefore, could be insignificant to a parasite's evolutionary past. On the other hand, definitive hosts can have long-term coevolutionary relationships with their parasites, or the host/parasite relationship could be acquired through host switching (e.g., Brooks and McLennan, 1993; Hoberg, 2005). Recent relationships from host switching could be the result of ecological fitting (resource tracking), in which the parasite is tracking a resource in the host rather than the host itself (Kethley and Johnston, 1975; Janzen, 1985; Brooks et al., 2006).

Significant movements of species caused by the dynamic geologic events of the Pleistocene might have brought together new sets of potential hosts and increased the incidence of host colonization (Hoberg and Brooks, 2007). Hence, determinants of host associations and their relationship to host specificity can be a complex phenomenon (Brooks et al., 2006). Molecular perspectives have proved key to revealing such complexity, especially in dynamic ecological situations such as those that existed in high latitudes over the past 2 million yr (Cook et al., 2005).

Evolutionary roles for a spectrum of potential and actual hosts, however, might be unclear for nematode parasites when there is difficulty in distinguishing minute morphological dif-

Received 5 January 2007; revised 27 March 2007; accepted 2 April 2007.

* United States National Parasite Collection, Animal Parasitic Diseases Laboratory, United States Department of Agriculture, Agricultural Research Service, Beltsville, Maryland 20705.

$\dagger$ Institute of Biological Problems of the North, Far Eastern Branch of the Russian Academy of Sciences, Magadan, Russia. ferences between species (cryptic species) or when trying to link together adult and juvenile forms. Juveniles are often difficult to identify to species because of undeveloped morphological characters essential to diagnosis (e.g., Jenkins et al., 2005). In these cases, molecular identification is necessary when trying to match juveniles in intermediate and paratenic hosts with adult nematodes in definitive hosts (McKeand, 1998).

Soboliphyme baturini Petrov, 1930, is a stomach-dwelling nematode and member of the monotypic Soboliphymatidae, Dioctophymidea (Karmanova, 1986). A complex life cycle characterizes $S$. baturini, with adult nematodes maturing in the stomach of the definitive host and females then releasing eggs that are shed in feces and deposited in the soil. In the leaf litter, the eggs are consumed by the intermediate host, enchytraeid oligochaetes, where they hatch, and the resulting juveniles develop to the infective third juvenile stage $\left(\mathrm{J}_{3}\right)$ and are later transmitted to mammals (Karmanova, 1986). Soricomorphs and rodents feed on these oligochaetes and could serve as paratenic hosts by bridging the trophic gap between mustelid and oligochaete, or the definitive host might consume enchytraeids directly and become infected by the nematode (Karpenko, 1985; Karpenko et al., 1998, 2007). Adult $S$. baturini can survive in the definitive host for up to $20 \mathrm{mo}$; therefore, annual cohorts could overlap, leaving the hosts constantly infected (Karmanova, 1986).

Over 50 mammal species and subspecies are recognized hosts for $S$. baturini (Appendix); however, Kontrimavichus (1985) suggested that not all of these are necessary to the life cycle. For example, felids and canids are incidental hosts, meaning the juveniles can survive in the host but fail to reach sexual maturity (Karmanova, 1986). More specifically, $S$. baturini is most commonly found in sable (Martes zibellina (Linnaeus)), American marten (Martes americana (Turton)), and Pacific marten (Martes caurina (Merriam)) and less frequently in ermine (Mustela erminea Linnaeus), wolverine (Gulo gulo (Linnaeus)), and mink (Neovison vison (Schreber)) (Petrov, 1930; Price, 1930; Shimakura and Odajima, 1934; Bezdek, 1942; Morgan, 1943; Schmidt and Kinsella, 1965; Swartz, 1968; Kontrimavichus, 1985; Karmanova, 1986; Sato et al., 1999; Rusin et al., 2003; Zarnke et al., 2004). 


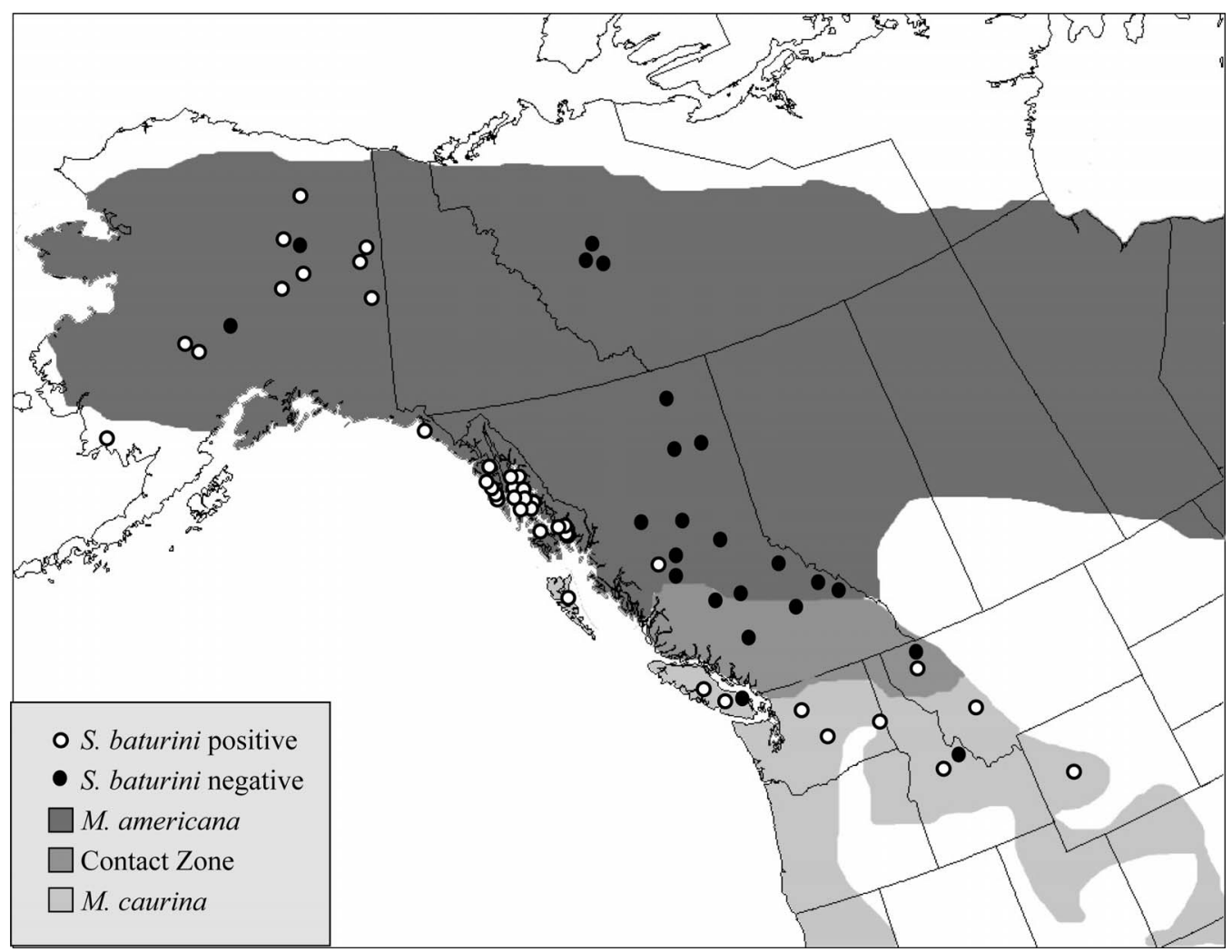

FIGURE 1. The geographic distributions of M. caurina and M. americana (modified from Hall, 1981) are overlapped with historic localities and survey results from this study for $S$. baturini. Admiralty and Kuiu Islands are the only islands known to support $M$. caurina in southeast Alaska. White dots represent occurrences of S. baturini. Black dots refer to necropsies of mustelids that were negative for $S$. baturini.

In North America, S. baturini is thought to be limited largely to the Pacific coast, with an eastward range extension to the southern Rocky Mountains. The southern range of this nematode coincides with the distribution of $M$. caurina, but intensive surveys need to be completed from southern and central British Columbia southward to northern New Mexico and northern California to adequately define this distribution. Further north, the nematode's distribution also includes the extreme western range of $M$. americana in southeast Alaska along the coast and in interior Alaska (Fig. 1). Occurrence of this nematode in $M$. americana apparently reflects 2 episodes of host switching (Koehler, 2006) in the Holocene, when M. americana expanded its range westward into both interior and coastal Alaska (Small et al., 2003).

Soboliphyme baturini is a prime candidate for studies that use molecular techniques to address the role of paratenic hosts in transmission and in exploring associations with definitive hosts. Worldwide host surveys over the past $76 \mathrm{yr}$ resulted in recognition of a variety of potential definitive, intermediate, and paratenic hosts; yet, the roles that each of these host species played in the evolution of this nematode remain unclear (Fig. 2; Appendix). Additionally, the specifics of the life cycle of $S$. baturini have yet to be completely deduced, including the role of shrews as paratenic hosts and designation of the potential host species as either definitive or incidental.

In this study, the distribution of $S$. baturini was assessed with the use of new and historical data. Additionally, the following questions are explored. First, does $S$. baturini represent a single widespread species, or is there evidence for cryptic species partitioned across 5 mustelid hosts (i.e., M. americana, M. caurina, M. zibellina, M. erminea, and N. vison)? Second, are soricomorphs paratenic hosts of $S$. baturini? These hypotheses are the foundation for assessing the life history and distribution of $S$. baturini.

\section{METHODS AND MATERIALS}

In conjunction with the Beringian Coevolution Project (Hoberg et al., 2003; Cook et al., 2005), adult and juvenile $S$. baturini were obtained from 21 geographic sites across eastern Siberia and the Pacific Northwest (Table I). Adult nematodes from North American localities were acquired through necropsies of 756 salvaged mustelid carcasses from commercial trappers, including $460 \mathrm{M}$. americana, $124 \mathrm{M}$. caurina, 59 Martes pennanti (Erxleben), 70 M. erminea, $40 \mathrm{~N}$. vison, 2 Taxidea taxus (Schreber), and 1 G. gulo (Table I). Of this total, 286 carcasses from interior British Columbia $(n=231)$, central Northwest Territories $(\mathrm{n}=45)$, and Montana and Idaho $(\mathrm{n}=10)$ (Table I) were studied to refine the eastern boundary of this nematode. Additional adult and juvenile specimens were obtained through collaborative efforts with other scientists (Appendix). Unpublished records from the U.S. National Parasite Collection (USNPC; USDA, Beltsville, Maryland) and from the University of Alaska Museum (AF; Fairbanks, Alaska) were also included. Specimens of adult $S$. baturini in stomachs of mustelids or $\mathrm{J}_{3}$ of presumptive $S$. baturini in diaphragms of soricids were preserved in 70 or $95 \%$ ethanol and stored at $-20 \mathrm{C}$ before analysis. Each specimen was subsampled, with the midsection of the body being reserved for molecular sequencing, and the head and tail of individual adults or $\mathbf{J}_{3}$ were archived as physical vouchers deposited in the Museum of Southwestern Biology (University of New Mexico, Albuquerque, New Mexico) (Table II)

Total genomic DNA was extracted from the midsections of individual 


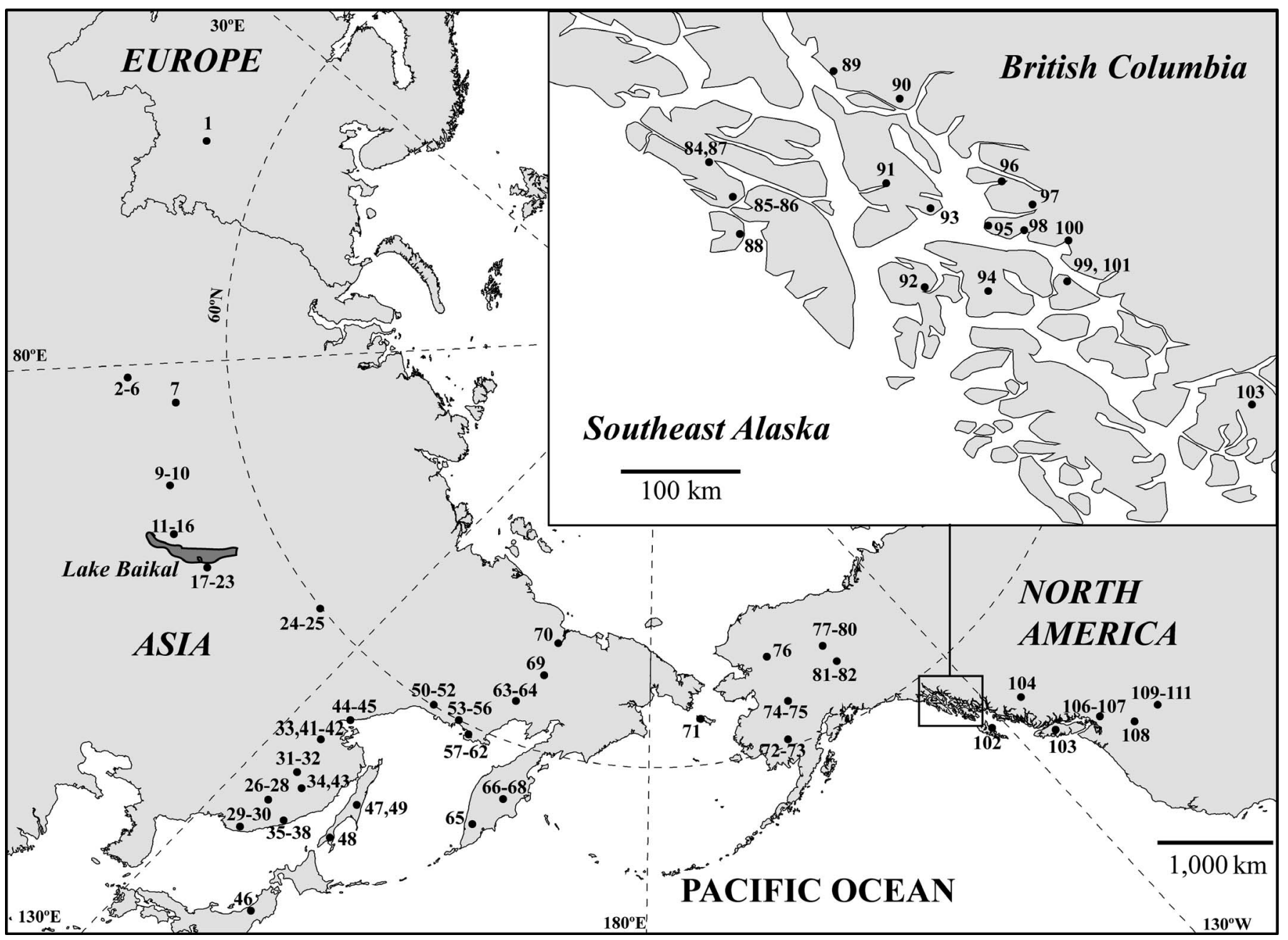

Figure 2. The distribution of $S$. baturini is based on published records and museum specimens and is centered on Beringia. Inset shows detail of localities in southeast Alaska. Numbers correspond to locality IDs in the Appendix.

worms with a commercial kit (AquaPure Genomic DNA Isolation Kit, Bio-Rad Laboratories, Hercules, California). A multilocus approach was employed to explore the potential for cryptic diversity in S. baturini. We assessed variation of 2 mitochondrial genes, nicotinamide dehydrogenase (ND4) and cytochrome oxidase I (COI). Phylogenetic species criteria (Adams, 1998; Brooks and McLennan, 2002; Nadler, 2002) were adopted in exploring whether $S$. baturini represents a single species among mustelids.

A 293-base pair (bp) region of the mitochondrial gene, COI (primers SoboCO1F 5'GCTCAGCTTCGGACAGTTTC3' and SoboCO1R 5'TCATGCAAATGAACATCTAGGG3'; Tran [2003]) was used to test for reciprocal monophyly including 3 representatives of $S$. baturini from major geographic localities within its range (Table III). Outgroups were Soboliphyme abei (Asakawa et al., 1988) in Sorex unguiculatus Dobson from Japan and Soboliphyme jamesoni Read, 1952, in Sorex tundrensis Merriam from Yakutsk, Russia. An additional outgroup includes Trichinella britovii Pozio, La Rosa, Murrell, and Lichtenfels, 1992; T. nativa Britov and Boev, 1972; and T. murelli Pozio and LaRosa, 2000.

The ND4 gene was used to further resolve the intraspecific phylogenies as suggested by Blouin (2002). A 243-bp region of ND4 was amplified from 8 worms (Table II) by polymerase chain reaction (PCR) with primers SoboND4F 5'GGGAGGGCCACTTACCTTAT3' and SoboND4R 5'GCCACAAACTTCTTCACGTCT3'. Primers for ND4 were designed with the use of Primer3 (Rozen and Skaletsky, 2000) on the basis of an alignment of published Xiphinema americanum Cobb, 1913 (GenBank NC005928), and Trichinella spiralis (Owen, 1835) (GenBank NC002681) ND4 genes.
Total reaction volumes were $25 \mu \mathrm{l}$ consisting of $14.25 \mu \mathrm{l}$ of $\mathrm{H}_{2} \mathrm{O}$; 1 $\mu \mathrm{l}$ of $10 \mu \mathrm{M}$ primer each; $1 \mu \mathrm{l}$ of DNA template $(\sim 5 \mathrm{ng} / \mu \mathrm{l}) ; 2.5 \mu \mathrm{l}$ each of $25 \mathrm{mM} \mathrm{MgCl}, 10 \mathrm{mM}$ DNTPs, and $10 \times$ PCR Buffer II; and $0.25 \mu 1$ of Taq (5 units/ $\mu 1$, Amplitaq ${ }^{\circledR}$, Applied Biosystems, Foster City, California). PCRs were run on PTC-200 thermocyclers (MJ Research, Waltham, Massachusetts) with the following parameters: initial denaturation at $94 \mathrm{C}$ for $60 \mathrm{sec}$, subsequent denaturations for $30 \mathrm{sec}$, annealing at $67 \mathrm{C}$ for $15 \mathrm{sec}$, and extension of $72 \mathrm{C}$ for $30 \mathrm{sec}$, repeated for an additional 34 cycles, followed with a final extension of $72 \mathrm{C}$ for $10 \mathrm{~min}$. Product was visualized via electrophoresis on a $0.8 \%$ agarose gel and cleaned with $30 \%$ polyethylene glycol (PEG) and QiaQuick ${ }^{\circledR}$ cleanup kit (Qiagen Inc., Germantown, Maryland). BigDye ${ }^{\circledR}$ Terminator v.3.1 (Applied Biosystems) was used for cycle sequencing reactions. Excess dyes and primer were removed with Sephadex ${ }^{\circledR}$ G-50 spin columns or sodium acetate ethanol wash (Applied Biosystems). Forward and reverse strands were sequenced with an ABI PRISM ${ }^{\circledR} 3100$ Genetic Analyzer.

Ambiguous sites were resolved with Sequencherix 4.6 (Genecodes, Ann Arbor, Michigan). Alignments were made with ClustalW (Chenna et al., 2003). All sequences were identical in length and no insertions or deletions were necessary. Mitochondrial sequences were translated to amino acids and examined for stop codons to check against pseudogenes. Sequences were deposited in GenBank, and physical vouchers were deposited in the Museum of Southwestern Biology (Table II). In total, 8 adult and $\mathrm{J}_{3}$ nematodes were sequenced from 6 mustelids and 2 soricids to examine the amount of sequence divergence among putative specimens of $S$. baturini (Table II). 
TABLE I. Locality data for mustelids that were examined for $S$. baturini throughout northwest North America. Prevalences and mean intensities of $S$. baturini from each locality are indicated.

\begin{tabular}{|c|c|c|c|c|c|c|c|c|}
\hline Scientific name & $\mathrm{n}$ & Prevalence & $\begin{array}{c}\text { Mean } \\
\text { intensity }\end{array}$ & Range & Locality & State/Province & Latitude & Longitude \\
\hline Gulo gulo & 1 & 0 & 0 & 0 & Yukon Flats & Alaska & 66.15 & -147.55 \\
\hline M. americana & 10 & 0 & 0 & 0 & Enderby & British Columbia, Canada & 50.68 & -119.05 \\
\hline M. americana & 22 & 4.5 & 1 & 1 & Francois Lake & British Columbia, Canada & 53.98 & -126.43 \\
\hline M. americana & 57 & 0 & 0 & 0 & Kootenai National Park & British Columbia, Canada & 50.47 & -115.67 \\
\hline M. americana & 17 & 94.1 & 27.3 & $10-53 \pm 15.2$ & Mitkof Island & Alaska & 56.68 & -132.92 \\
\hline M. americana & 45 & 0 & 0 & 0 & Norman Wells & Northwest Territories, Canada & 65.23 & -127.00 \\
\hline M. americana & 5 & 0 & 0 & 0 & Prince George & British Columbia, Canada & 54.44 & -123.39 \\
\hline M. americana & 9 & 22.2 & 5.5 & $2-9 \pm 4.9$ & Revillagigedo Island & Alaska & 55.77 & -131.60 \\
\hline M. americana & 10 & 0 & 0 & 0 & Smithers & British Columbia, Canada & 54.75 & -126.65 \\
\hline M. americana & 133 & 53.4 & 12 & $1-80 \pm 15.9$ & Thomas Bay & Alaska & 57.02 & -132.85 \\
\hline M. americana & 41 & 2.4 & 1 & 1 & Yukon Flats & Alaska & 66.15 & -147.55 \\
\hline M. pennanti & 59 & 0 & 0 & 0 & Central BC & British Columbia, Canada & 52.00 & -123.67 \\
\hline Mustela erminea & 10 & 0 & 0 & 0 & 100-Mile House & British Columbia, Canada & 51.71 & -121.55 \\
\hline M. erminea & 2 & 50 & 1 & 1 & Admiralty Island & Alaska & 57.20 & -134.29 \\
\hline M. erminea & 10 & 0 & 0 & 0 & Fort Nelson & British Columbia, Canada & 58.83 & -123.75 \\
\hline M. erminea & 10 & 0 & 0 & 0 & Kupreanof Island & Alaska & 56.79 & -133.50 \\
\hline M. erminea & 11 & 0 & 0 & 0 & Mitkof Island & Alaska & 56.68 & -132.92 \\
\hline M. erminea & 1 & 0 & 0 & 0 & Queen Charlotte Islands & British Columbia, Canada & 53.25 & -132.00 \\
\hline M. erminea & 7 & 0 & 0 & 0 & Smithers & British Columbia, Canada & 54.75 & -126.65 \\
\hline M. erminea & 5 & 0 & 0 & 0 & Thomas Bay & Alaska & 57.02 & -132.85 \\
\hline M. erminea & 7 & 0 & 0 & 0 & Vancouver Island & British Columbia, Canada & 49.17 & -123.93 \\
\hline Neovison vison & 1 & 0 & 0 & 0 & 100-Mile House & British Columbia, Canada & 51.71 & -121.55 \\
\hline N. vison & 5 & 0 & 0 & 0 & Enderby & British Columbia, Canada & 50.68 & -119.05 \\
\hline
\end{tabular}

TABLE II. Specimens of S. baturini used in constructing the haplotype network for ND4 sequences. Specimens were obtained through the Beringian Coevolution Project or other collaborators throughout the Beringian region. Museum of Southwestern Biology and GenBank accession numbers, host species, host status (definitive or paratenic), and locality data are included.

\begin{tabular}{|c|c|c|c|c|c|c|c|}
\hline NK 135687 & EF457895 & Martes americana & Definitive & U.S. & Kupreanof Island & 56.73 & -133.57 \\
\hline NK 128108 & EF457893 & M. americana & Definitive & U.S. & Fairbanks, Alaska & 65.18 & -146.58 \\
\hline NK 159571 & EF457891 & M. zibellina & Definitive & Russia & Kamchatka & 56.00 & 160.00 \\
\hline NK 122064 & EF457890 & Mustela erminea & Definitive & U.S. & Admiralty Island & 57.44 & -133.84 \\
\hline NK 122289 & EF457896 & Neovison vison & Definitive & U.S. & Mitkof Island & 56.68 & -132.92 \\
\hline
\end{tabular}


TABLE III. Specimens of Soboliphyme used in constructing the MrBayes tree for COI sequences. Specimens were obtained through the Beringian Coevolution Project or other collaborators throughout the Beringian region. Museum of Southwestern Biology and GenBank accession numbers, host species, and locality data are included.

\begin{tabular}{|c|c|c|c|c|c|c|c|}
\hline Specimen & GenBank & Species & Host species & Country & Locality & Latitude & Longitude \\
\hline NK 135687 & EF519531 & Soboliphyme baturini & Martes americana & U.S. & Kupreanof Island & 56.73 & -133.57 \\
\hline NK 128108 & EF519532 & S. baturini & M. americana & U.S. & Fairbanks, Alaska & 65.18 & -146.58 \\
\hline NK 159571 & EF519530 & S. baturini & M. zibellina & Russia & Kamchatka & 56.00 & 160.00 \\
\hline NK 139168 & EF519533 & S. jamesoni & Sorex tundrensis & Russia & Yakutsk & 62.02 & 129.61 \\
\hline NK 139584 & EF519534 & S. jamesoni & S. roboratus & Russia & Yakutsk & 62.07 & 128.94 \\
\hline NK 159581 & EF519535 & S. abei & S. unguiculatus & Japan & Hokkaido & 43.05 & 141.35 \\
\hline NA & DQ007892 & Trichinella britovi & NA & NA & NA & NA & NA \\
\hline NA & DQ007894 & T. murrelli & NA & NA & NA & NA & NA \\
\hline NA & AB252966 & T. nativa & NA & NA & NA & NA & NA \\
\hline
\end{tabular}

Maximum parsimony (MP) optimality criteria was used for phylogenetic reconstruction by PAUP* (Swofford, 2002), considering all characters as unordered with 4 possible states (A, C, G, T); uninformative characters were excluded from the MP analysis. A branch and bound search was performed with COI sequences. Node support was evaluated with nonparametric bootstrap methodology and the use of 5,000 replicates for MP (Felsenstein, 1985). The Markov chain Monte Carlo (MCMC) sampling procedure was performed by the program MrBayes (Ronquist and Huelsenbeck, 2003) to estimate the posterior probability of phylogenetic trees. The program was executed twice with 5,000,000 generations run, 4 heated chains, and 45,000 trees saved. The median joining algorithm (Bandelt et al., 1999) in the program Network v4.1.1.2 (Fluxus Engineering, Suffolk, U.K.) was used to create a haplotype network for the 8 sequences of the ND4 gene (Table II).

\section{RESULTS}

\section{Host surveys}

Examination of historical accounts of $S$. baturini, along with data from the current study (Appendix), indicate that $S$. baturini is found predominantly in $M$. americana, $M$. caurina, and $M$. zibellina. Of 756 mustelids necropsied, 204 (27\%) were infected and 3,674 specimens of S. baturini were recovered (Fig. 1; Table I). No $S$. baturini were found in $G$. gulo $(\mathrm{n}=1), M$. pennanti $(\mathrm{n}=59)$, or $T$. taxus $(\mathrm{n}=2)$. Only $1 M$. erminea $(\mathrm{n}$ $=70)$ and $1 N$. vison $(\mathrm{n}=40)$ were infected, both in southeast Alaska. The highest prevalence of $S$. baturini in $M$. americana was from southeast Alaska. Of those hosts surveyed near the eastern boundary of the known range for $S$. baturini, only 1 worm was found (Francois Lake, interior British Columbia, $\mathrm{n}$ $=114)$ and none was found in the Northwest Territories $(\mathrm{n}=$ 45). Martes caurina had the highest prevalence of infection on Admiralty Island $(88 \%)$ and $M$. americana had highest prevalences on Kuiu (79\%), Kupreanof (85\%), and Mitkof islands $(94 \%)$.

\section{Assessment of distribution from current and historical data}

Records of occurrence of S. baturini in North America, including those from this study, were mapped over the current distribution of the principle hosts, $M$. americana and $M$. caurina (Fig. 1). Two equivocal historical records of $S$. baturini occurred farther east in North America. A specimen of $S$. $b a$ turini reported from Madison, Wisconsin (Morgan, 1943), is unsubstantiated because the author does not refer to any specific locality. This specimen was identified at the USNPC by B. Chit- wood in 1933, where the practice used at that time often referred geographic records to the city or laboratory, rather than to the actual geographic origin of the specimen. Another account of $S$. baturini was recovered in a single wolverine $(G$. gulo) from the province of Quebec, Canada (Bezdek, 1942). Because wolverines are long-distance dispersers (Hornocker and Hash, 1981) and infections of S. baturini can persist for 20 mo (Karmanova, 1986), this record might have been a chance dispersal event. Alternatively, that specimen could have been sent to a laboratory in Quebec from a western locality. If these 2 records are discounted, then the eastern limit of viable $S$. baturini populations would be the Rocky Mountains. We suggest this to be the case on the basis of the ease of detection of this large stomach-dwelling nematode combined with a series of published assessments of diets of mustelids in North America. In addition, extensive parasitological surveys of mustelids and other potential carnivore hosts east of the Rocky Mountains have not detected this parasite (Erickson, 1946; Meyer and Chitwood, 1951; Dick and Leonard, 1979; Jennings and Threlfall, 1982; Poole et al., 1983).

The Old World distribution of $S$. baturini appears limited to the region east of the Ural Mountains. Accounts of S. baturini west of the Urals may be attributed to human translocations of M. zibellina from the Baikal region after their earlier extirpation (Monakhov, 2001).

\section{Molecular identification of nematodes}

Molecular analysis does not refute the hypothesis that $S$. baturini is a single widespread species. Sequences of COI from 3 putative adult $S$. baturini representing populations from disparate geographic localities in the Nearctic and Palearctic exhibited minimal variation, and MP analyses unequivocally demonstrated reciprocal monophyly relative to the presumptive sister species $S$. abei and S. jamesoni (Fig. 3). After initial assessment of this locus aimed at species-level identification, our focus shifted from COI to ND4 on the basis of expectations of greater variability and information content to explore variation in worms from different hosts at particular sites.

Sequences at the ND4 locus could not be reliably aligned between $S$. baturini and respective outgroups. Minimal diversity was demonstrated in sequences of ND4 for 6 adults and $2 \mathbf{J}_{3}$ larvae. Nematodes found in different mustelid hosts collected from similar geographic locations had identical sequences for 


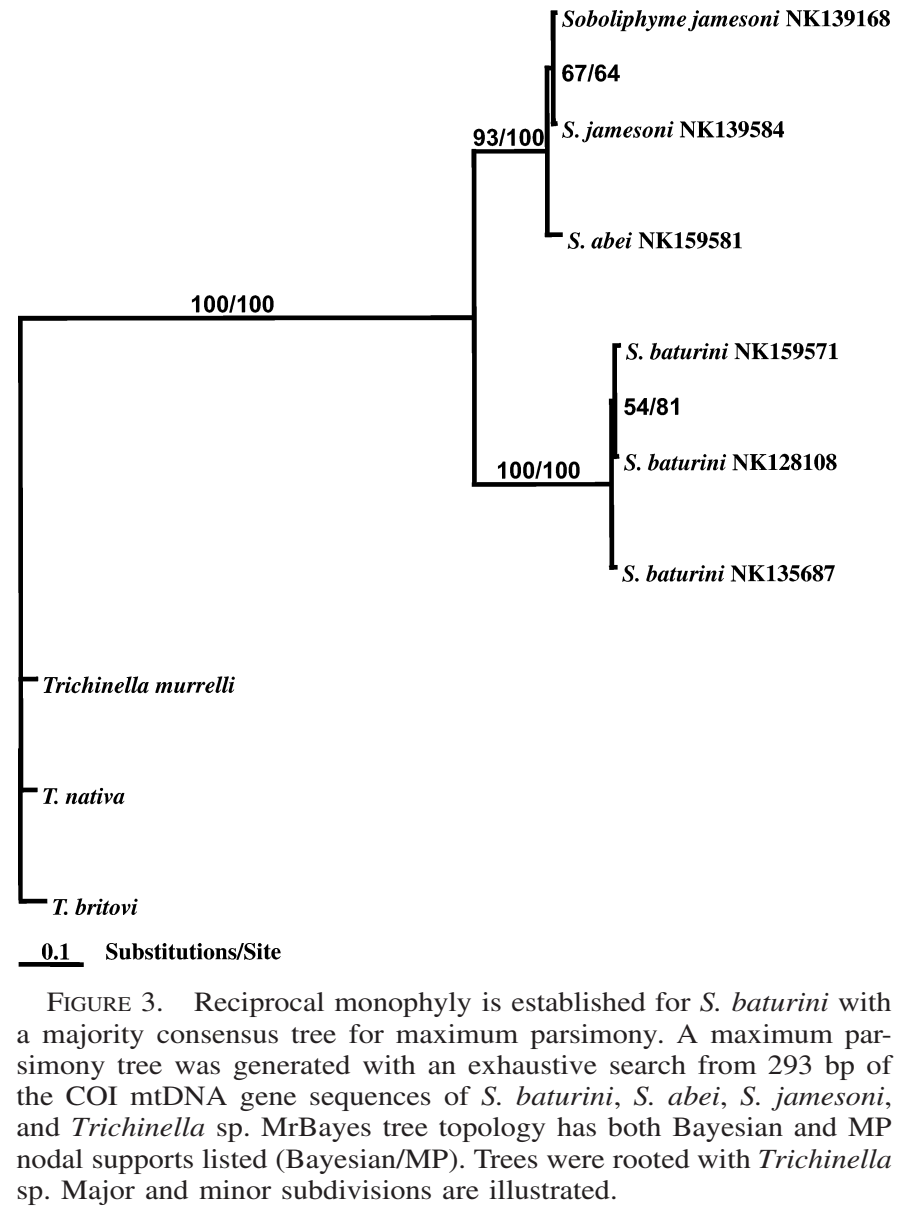

central southeast Alaska (M. americana, N. vison) and Admiralty Island (M. caurina, M. erminea), respectively (Fig. 4). Sequences of specimens from putative $S$. baturini in soricids from Russia and Alaska also were identical or differed minimally when compared with worms inhabiting mustelids from the same geographic regions (Fig. 4). For example, nematode sequences from $M$. zibellina and $S$. unguiculatus Dobson were identical and differed by only 2 bp between $M$. americana and S. cinereus Kerr collected from 2 localities separated by 300 $\mathrm{km}$ in interior Alaska. This is evidence that shrews are paratenic hosts and that at any particular locality these worms are infecting a variety of hosts. Additionally, diet of New World marten and Old World sable (Table IV) indicated that shrews are consumed frequently.

\section{DISCUSSION}

\section{Sampling}

Identifying the role of putative hosts in a parasite's life cycle (e.g., definitive, intermediate, or paratenic) is essential to understanding the evolutionary history and assessing the significance of processes such as ecological fitting in host/parasite dynamics. Wide taxon and geographic sampling is required to first document the range of a parasite, identify species limits, and characterize the role of component hosts. Here, we establish species identity, describe the geographic range, and identify the

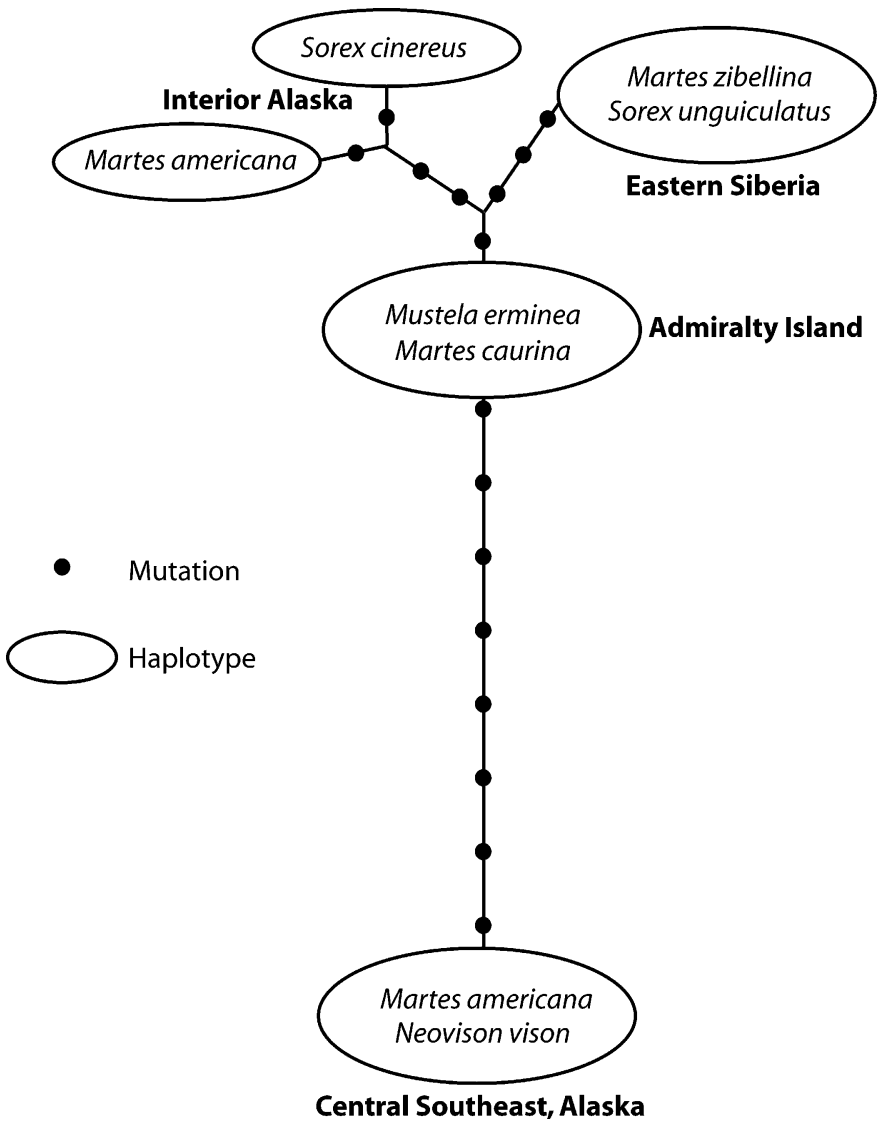

FIGURE 4. Network of $S$. baturini haplotypes (243 bp of the ND4 gene) constructed by the median joining method. Juvenile $S$. baturini (soricid hosts) are similar to adult $S$. baturini (mustelid hosts). Nematodes of Neovison vison and $M$. erminea are identical to nematodes in $M$. caurina and $M$. americana. Dots represent mutational changes. Ovals indicate haplotypes.

paratenic and definitive host associations of the Holarctic nematode, S. baturini.

\section{Genetic diversity and species}

Minimal genetic diversity was observed in putative populations of S. baturini (Fig. 3; Table III). Application of phylogenetic criteria (e.g., Adams, 1998; Brooks and McLennan, 2002; Nadler, 2002) establishes $S$. baturini as a single species. Cryptic species and species complexes have been reported and predicted among assemblages of Beringian helminths, including nematodes and cestodes (Hoberg et al., 1999; Haukisalmi, $2001,2004)$ as a consequence of the complex history of faunal expansion and geographic colonization and isolation in this region. Among a diversity of parasitic helminths, minimal variation in morphological characters contrasts with "hidden molecular diversity," a general phenomenon for helminths in Beringia and elsewhere (Hoberg et al., 2003; Haukisalmi et al., 2004; Cook et al., 2005). Soboliphyme baturini might be an exception to this generality (Koehler, 2006). Molecular comparisons did not detect substantial genetic variation among nematodes from different hosts, a finding consistent with the hypothesis that $S$. baturini represents a single species across its wide geographic range that spans Beringia (Koehler, 2006). 
Low genetic diversity, multiple hosts, and relatively widespread geographic distribution suggest a shallow temporal association for $S$. baturini and mustelids that could be compatible with a history of geological and host colonization. Molecular characterization of S. baturini occurring in G. gulo and M. pennanti is still needed.

\section{Geographic range and life cycle}

The distribution of $S$. baturini in marten from 3 major localities throughout Alaska was mapped (Zarnke et al., 2004; Fig. 1) on the basis of the following prevalences: northern $(19 \%, \mathrm{n}=2,166)$, southwestern $(30 \%, \mathrm{n}=1,058)$, and southeastern $(47 \%, \mathrm{n}=3,028)$. Our expanded survey of marten and other mustelid hosts demonstrated high prevalences in southeast Alaska $(64 \% \mathrm{n}=334)$. Only 1 worm was found east of the Coast Range (Table I; Fig. 1), suggesting that the distribution of $S$. baturini is restricted primarily to the Pacific Northwest.

The absence of $S$. baturini in central and eastern North America can be attributed to the distribution of intermediate hosts required for transmission. Experimental evidence found that only oligochaetes from the Enchytraeidae were suitable hosts for development of S. baturini (Karmanova, 1963). Enchytraeids are found on every continent, with greatest abundance in moist temperate regions (O'Connor, 1967). Karmanova (1986) concluded that the distribution of S. baturini was dependant on geography and meteorological conditions and potentially limited by availability of suitable enchytraeids. She found $S$. baturini most common in floodplains of major rivers in eastern Asia where enchytraeids thrive in areas of humid forest litter. During periods of drought, enchytraeids survive near water sources but perish during periods of extended flooding. Kaufmann et al. (2002) showed that enchytraeids colonize soils within $40 \mathrm{yr}$ of deglaciation, so their distribution would be limited by rates of geographic expansion as glaciers retreat. Consequently, the temperate rainforest climate of southeast Alaska and associated refugial habitats appear to have been ideal for the persistence of $S$. baturini during full glacial advances of the Late Pleistocene (Koehler, 2006). Future identification of specific enchytraeids capable of hosting $S$. baturini, and then careful documentation of the distributions of these hosts, could substantially broaden our understanding of the geographic limits of this nematode.

Among the vast array of definitive hosts examined (Appendix), only a few are thought to be important to the life cycle of S. baturini. Reviews by Kontrimavichus (1985) and Karmanova (1986) concluded that marten and sable were the principle definitive hosts. In North America, coastal Alaska and British Columbia have a high prevalence of $S$. baturini in both $M$. caurina and $M$. americana $(59 \%, \mathrm{n}=362)$, whereas other mustelids (i.e., $N$. vison [25\%, $\mathrm{n}=4]$ and M. erminea [3\%, $\mathrm{n}=36]$ ) had lower prevalence, although sample size is low for both. If $N$. vison and $M$. erminea were essential to the life cycle of $S$. baturini, one might expect higher prevalence and the parasite should be common in those hosts when marten are not in sympatry.

Kontrimavichus (1962) examined 707 mustelids from the Khabarovsk region of the Russian Far East, including $281 \mathrm{~N}$. vison (91\% infected), 196 M. sibirica Pallas (39\% infected), and 196 M. zibellina (70\% infected). The author noted that $N$. vison might be more susceptible to infection because of close association with water. Larger samples of $N$. vison are needed in North America to effectively understand the role of this host in the Pacific Northwest.

Sporadic cases of S. baturini in G. gulo have been reported from Montana (Price, 1930), Quebec (Bezdek, 1942), and interior Alaska (USNPC 033728). Rausch (1959) examined 108 G. gulo from throughout northern and interior Alaska and reported no $S$. baturini. When found in G. gulo, specimens have been mature adults. The Holarctic distribution (Wilson and Reeder, 2005) and large dispersal capabilities for wolverines (Hornocker and Hash, 1981) suggest they may have been crucial to the dissemination and maintenance of $S$. baturini throughout its geographic range. Another mustelid, M. pennan$t i$, has been recorded as a host to $S$. baturini in Montana (USNPC 067206) and in southeast Alaska (AF 24441). The absence of $S$. baturini in $59 \mathrm{M}$. pennanti collected from throughout British Columbia and 162 M. pennanti from Manitoba (Dick and Leonard, 1979) reinforces the conclusion that $M$. pennanti is an uncommon host for $S$. baturini. Populations of $M$. pennanti in Washington, Oregon, and Montana should be screened for $S$. baturini. The appearance of $S$. baturini in $M$. pennanti could be the result of ecological fitting (Janzen, 1985; Brooks et al., 2006), where parasites track a resource provided by the host, rather than as a manifestation of the host specificity. Ecological fitting could be applied to other hosts (e.g., N. vison and $M$. erminea) as well because deep coevolutionary, or even cophylogeographic relationships, have not been demonstrated (Koehler, 2006). A temporally shallow association is consistent with minimal genetic diversity relative to hosts and geography.

When the situation arises, $S$. baturini can infect other species because resources required to complete its life cycle are available. In addition to the potential role of refugia (e.g., coastal and Beringia) in the evolution of this nematode (Fleming and Cook, 2002; Cook et al., 2006), resources available to $S$. baturini in marten apparently are optimal along the coast and in interior Alaska. Zarnke et al. (2004) arrived at a similar conclusion, suggesting that some environmental condition in southeast Alaska favors the survival and transmission of $S$. baturini.

Absence of $S$. baturini from European marten (Martes martes (Linnaeus) or Martes foina (Erxleben)) could result from constraints of historical biogeography ( $S$. baturini never occurred in Europe), diet (paratenic or intermediate hosts), or features of the hosts related to this nematode's ability to track resources available only in M. americana, M. caurina, and M. zibellina. For comparison with another nematode, $M$. martes and $M$. foina are hosts to Skrjabingylus petrowi Bageanov, 1936. This nematode of the frontal sinuses does not occur naturally in $M$. zibellina or North American marten (Kontrimavichus, 1985; Kontrimavichus et al., 1985; Koubek et al., 2004). As with $S$. baturini, soricids have been implicated as paratenic hosts for species of Skrjabingylus (Gamble and Riewe, 1982). Hence, diet does not appear to be a limiting factor in the contrasting distributions of these 2 nematodes because soricids are eaten by $M$. foina and M. martes (Clevenger, 1994; Helldin, 1999).

Soboliphyme baturini might fail to achieve sexual maturity in M. erminea. Schmidt and Kinsella (1965) reported juvenile $S$. baturini in M. erminea collected near Juneau, Alaska. Mustela erminea from our study were infected only by juvenile $S$. baturini. Additional specimens of this nematode recovered from 
TABLE IV. Summary of diet analyses of Martes spp. used to determine whether shrews are important to the diet of Martes spp. Studies are from a range of localities throughout the Palearctic and Nearctic distribution of Martes spp. Studies examined stomach contents unless otherwise noted. The amount of vegetation and soil debris in the diet is also reported.

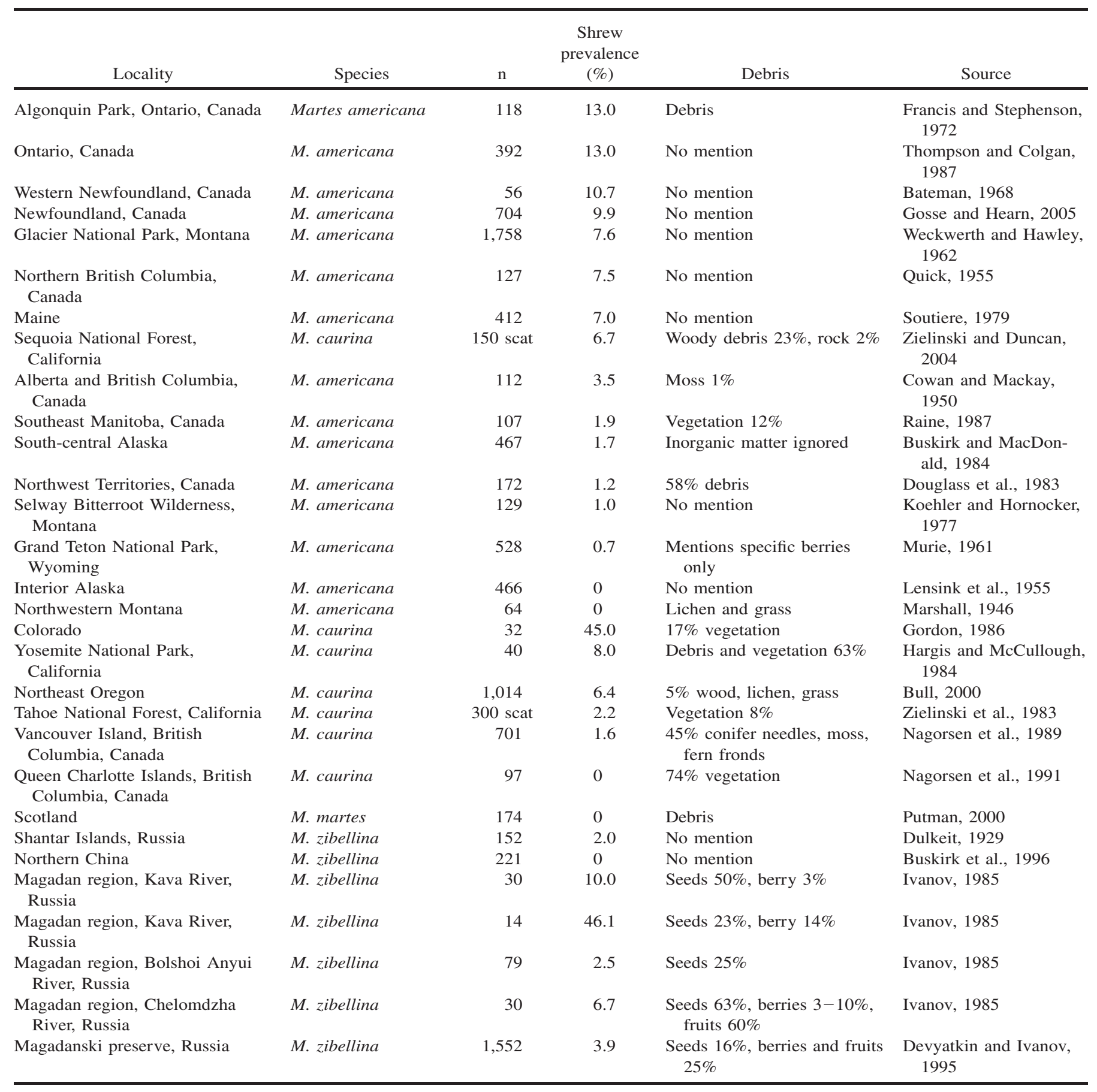

M. erminea are needed to fully explore this contention. Scarcity of $S$. baturini in $M$. erminea might also be attributed to the relatively large size of the nematode, a factor that might inhibit its occurrence in the stomach of smaller mustelids. Constraints of host and parasite body size are reviewed in Poulin (1998). Therefore, ermine could be considered an incidental host and subsequently might not be significant in shaping the evolutionary past of $S$. baturini.

\section{Paratenic hosts, diet, and transmission}

Experimental infections by ingestion found that only oligochaetes from the Enchytraeidae were suitable intermediate hosts for S. baturini (Karmanova, 1963). Whether the definitive host directly consumes the infected enchytraeid or is first eaten by a paratenic host has been debated (Domnich, 1982; Karpenko, 1985; Kontrimavichus, 1985; Karmanova, 1986; Karpenko et 
al., 1998, 2007; Dokuchaev, 2003; Zarnke et al., 2004). Domnich (1982) proposed that shrews serve as paratenic hosts on the basis of morphological similarities between adult $S$. baturini in mustelids and encysted juvenile nematodes in the diaphragms of shrews. Dokuchaev $(2001,2003)$ concluded that the high prevalence of juvenile $S$. baturini (up to 50 ) in soricids was a sufficient year-round source for the maintenance of infection in mustelids.

Molecular evidence revealed that $\mathbf{J}_{3}$ nematodes in shrews were identical to definitively identified adult $S$. baturini in mustelids (Fig. 4) from the same localities, thus lending support to the hypothesis that a paratenic relationship exists. Recovery of mature $S$. baturini from a mustelid that was fed juvenile nematodes from infected shrews would unequivocally demonstrate a role in transmission for species of Sorex and perhaps other soricomorphs.

Juvenile $S$. baturini found in the diaphragms of shrews should not be confused with adults representing 8 other species of Soboliphyme known to reach sexual maturity in the stomachs of soricomorphs (S. abei, Asakawa et al., 1988; S. ataahai Ganzoring et al., 2002; S. caucassica Matsaberidze, 1965; S. hirudiniformis Kirshenblat, 1964; S. jamesoni Read, 1952; S. occidentalis Ribas and Casanova, 2004; S. soricis Baylis and King, 1932; S. urotrichi Machida and Uchida, 1982). Karpenko et al. (2007) reported finding juvenile $S$. baturini in species of Sorex from Asia and for the first time from North America. Juvenile $S$. baturini have also been reported in Myodes rufocanus (Sundevall) (Karpenko et al., 1998), but their identity has not been confirmed with molecular genetic assessment.

Existing literature on diets of $M$. americana and $M$. caurina indicates that these mustelids eat shrews (Table IV). Of the 27 papers examined on marten diet, $81 \%$ reported shrews in the diet. Shrews composed $8.8 \%$ of the diet on average, with a range of $0.7 \%$ to $46 \%$. Gordon (1986) reported that $45 \%$ of the diet in a population of Colorado marten consisted of shrews. She hypothesized that marten consumed shrews during severe winters when the typical prey base was unavailable. An alternative hypothesis regarding mustelid infections of $S$. baturini would be the ingestion of oligochaetes, either accidentally with debris on food items or by direct consumption. About $50 \%$ of the diet literature examined mentioned plant or soil debris in the host digestive tracts (Table IV); thus, the exact mechanism for infection could involve multiple pathways.

Molecular evidence now links the juveniles of $S$. baturini in shrews with mature $S$. baturini in definitive mustelid hosts at the same geographic locations. Shrew consumption by marten also has been thoroughly documented. What remains unresolved is the extent to which marten hosts become infected with $S$. baturini as a result of consuming infected shrews. Soricomorphs are distributed throughout a variety of habitats (Nagorsen et al., 1996) and are frequently sympatric with mustelids. The abundance of shrews, and prevalence of infection for $S$. baturini in potential paratenic hosts, might serve as key determinants of the distribution of this nematode among mustelids across high-latitude environments. In turn, the use of parasitic juvenile and egg stages greatly increases the availability and scope of material to phylogeneticists and population geneticists, who often lack sufficient samples from remote or politically inaccessible localities (e.g., Jenkins et al., 2005).

\section{ACKNOWLEDGMENTS}

N. Tranbenkova contributed specimens from Kamchatka, Russia; J. Whitman contributed specimens from Chichagof Island, McGrath, and Fairbanks, Alaska. M. Asakawa provided specimens from Japan. D. Nagorsen contributed worms from British Columbia, Canada. We thank S. V. Brant, K. E. Galbreath, and D. W. Duszynski for their helpful comments. Additional specimens and logistical assistance were kindly provided by M. Fleming, R. Flynn, D. Hatler, K. Marsh, E. Crain, R. Popko, E. Lofroth, N. Panter, and H. Schwantje. Technical support with laboratory procedures was provided by J. Dragoo, D. Zarlenga, B. Rosenthal, S. Nadler, F. Torres-Pérez, M. Esteva, M. Taylor, B. Hyman, S. Tang, B. Hanelt, M. Steinauer, C. Adema, and G. Rosenberg. Special thanks to T. Orr, N. Dawson, D. Crawford, E. Waltari, A. Runck, B. Weckworth, A. Hope, J. Malaney, L. Harding, S. MacDonald, and other members of the Cook Lab and the Biology Molecular Core Facility. Specimen preparation was assisted by J. Bennett, D. Villanueva, M. Dimas, K. Ortega, and M. Marshall. This research is a contribution of the Beringian Coevolution Project funded by the National Science Foundation through grants from the Biotic Survey and Inventory program (DEB 0196095 and 0415668). Further funding was provided by the National Park Service, USDA Forest Service, U.S. Fish and Wildlife Service, and the University of New Mexico (Student Research Allocations Committee and Graduate Research Allocations Committee). In Russia, this work was partly supported by the Russian Fund for Fundamental Research (05-04-49010).

\section{LITERATURE CITED}

AdAMs, B. J. 1998. Species concepts and the evolutionary paradigm in modern nematology. Journal of Nematology 30: 1-21.

Bandelt, H. J., P. Forster, AND A. RÖHL. 1999. Median-joining networks for inferring intraspecific phylogenies. Molecular Biology and Evolution 16: 37-48.

Bateman, M. C. 1968. Winter habitat use, food habits and home range size of the Marten, Martes americana, in Western Newfoundland. Canadian Field Naturalist 100: 58-62.

BezdeK, H. 1942. Studies on the nematode Soboliphyme baturini Petrow, 1930. Transactions of the American Microscopical Society 61: 393-403.

BLouin, M. S. 2002. Molecular prospecting for cryptic species of nematodes: Mitochondrial DNA versus internal transcribed spacer. International Journal for Parasitology 32: 527-531.

Brooks, D. R., And D. A. McLennan. 1993. Parascript: Parasites and the language of evolution. Smithsonian Institution Press, Washington, D.C., 429 p.

, AND 2002 . The nature of diversity: An evolutionary voyage of discovery. The University of Chicago Press, Chicago, Illinois, $668 \mathrm{p}$

, - V. LeÓn-RÈgagnon, And E. P. Hoberg. 2006. Phylogeny, ecological fitting and lung flukes: Helping solve the problem of emerging infectious diseases. Revista Mexicana de Biodiversidad 77: 225-233.

Bull, E. L. 2000. Seasonal and sexual differences in American Marten diet in northeastern Oregon. Northwest Science 74: 186-191.

Buskirk, S. W., Y. Ma, L. XU, AND Z. JiAnG. 1996. Diets of, and prey selection by sables (Martes zibellina) in northern China. Journal of Mammalogy 77: 725-730.

- AND S. O. MACDONALD. 1984. Seasonal food habits of marten in south-central Alaska. Canadian Journal of Zoology 62: 944-950.

Chenna, R., H. Sugawara, T. Koike, R. Lopez, T. J. Gibson, D. G. Higgins, And J. D. Thompson. 2003. Multiple sequence alignment with the Clustal series of programs. Nucleic Acids Research 31: 3497-3500.

Clevenger, A. P. 1994. Feeding ecology of Eurasian pine martens and stone martens in Europe. In Martens, sables, and fishers: Biology and conservation, S. W. Buskirk, A. S. Harestad, M. G. Raphael, and R. A. Powell (eds.). Cornell University Press, Ithaca, New York, p. 326-340.

Cook, J. A., N. G. Dawson, and S. O. MacDonald. 2006. Conservation of highly fragmented systems: The north temperate Alexander Archipelago. Biological Conservation 133: 1-15. , E. P. Hoberg, A. Koehler, H. Henttonen, L. Wickström, V. 
Haukisalmi, K. Galbreath, F. Chernyavski, N. Dokuchaev, and A. LAHZUHTKIN. 2005. Beringia: Intercontinental exchange and diversification of high latitude mammals and their parasites during the Pliocene and Quaternary. Mammal Study 30: S33-S44.

COWAN, I., AND R. H. MACKAY. 1950. Food habits of the marten (Martes americana) in the Rocky Mountain region of Canada. The Canadian Field-Naturalist 64: 100-104.

DevyatKin, G. V., AND V. V. Ivanov. 1995. The ecology of sable (Martes zibellina L.) in "Magadanski" preserve. In Fauna and ecology of the mammals in north-east Siberia, V. G. Krivosheev (ed.). NESC FEB RAS, Magadan, Russia, p. 62-71.

Dick, T. A., AND R. D. LeONARD. 1979. Helminth parasites of fisher Martes pennanti (Erxleben) from Manitoba, Canada. Journal of Wildlife Diseases 15: 409-412.

Dokuchaev, N. E. 2001. Significance of the shrews as paratenic hosts of nematodes Soboliphyme baturini. Overall results and prospects of the development of the mammalogy in Siberia. In Proceedings of the First Scientific Conference. 24-26 May 2001. Irkutsk, Russia, p. 237-240.

- 2003. Distribution of nematodes Soboliphyme genus in shrews (Sorex) in the East of Russia. Theriological Investigations. Issue IV. Zoological Institute Russian Academy of Sciences, Saint Petersburg, Russia, p. 86-92.

Domnich, I. F. 1982. Shrew as paratenic hosts of nematode Soboliphyme baturini. Parasitologiya 16: 497-499.

_, AND I. N. OBUShENKov. 1983. Gel'mintofauna khishchnykh mlekopitaiushchikh severovostochnoi Azii. Institut Biologicheskikh Problem Severa, Dal'nevostochnyi Nauchnyi Tsentr, Akademiia Nauk SSSR, Magadan, U.S.S.R., 17 p.

Douglass, R. J., L. G. Fisher, AND M. MaIR. 1983. Habitat selection and food habits of marten, Martes americana, in the Northwest Territories. The Canadian Field-Naturalist 97: 71-74.

Dulkeit, G. 1929. Biologie und Gewerbejagd des Zobels auf den Schantarskii-Iseln. Bulletin of Pacific Fishery Resource Station 3: $1-119$.

ERICKSON, A. B. 1946. Incidence of worm parasites in Minnesota Mustelidae and host lists and keys to North American species. American Midland Naturalist 36: 494-509.

Felsenstein, J. 1985. Confidence limits on phylogenies: An approach using the bootstrap. Evolution 39: 783-791.

Fleming, M. A., AND J. A. CooK. 2002. Phylogeography of endemic ermine (Mustela erminea) in Southeast Alaska. Molecular Ecology 11: 795-808.

Francis, G. R., AND A. B. STEPHENSON. 1972. Marten ranges and food habits in Algonquin Provincial Park, Ontario. Ontario Ministry of Natural Resources Wildlife Report 91, Ottawa, Ontario, 53 p.

Gamble, R. L., AND R. R. Riewe. 1982. Infestations of the nematode Skrjabingylus nasicola (Leukart 1842) in Mustela frenata (Lichtenstein) and M. erminea (L.) and some evidence of a paratenic host in the life cycle of this nematode. Canadian Journal of Zoology 60: $45-52$.

Gordon, C. G. 1986. Winter food habits of the pine marten in Colorado. Great Basin Naturalist 46: 166-168.

Gosse, J. W., And B. J. Hearn. 2005. Seasonal diets of Newfoundland martens, Martes americana atrata. Canadian Field-Naturalist 119: 43-47.

Gubanov, N. M. 1964. Helminth fauna of the trade mammals of Yakutiya. Nauka, Moscow, Russia, 164 p.

HaLl, E. R. 1981. The mammals of North America, 2nd ed. John Wiley and Sons, New York, New York, 1,181 p.

Hargis, C. D., AND D. R. McCullough. 1984. Winter diet and habitat selection of marten in Yosemite National Park. Journal of Wildlife Management 48: 140-146.

Haukisalmi, V., L. M. Wickström, J. Hantula, and H. Henttonen. 2001. Taxonomy, genetic differentiation and Holarctic biogeography of Paranoplocephala spp. (Cestoda: Anoplocephalidae) in collared lemmings (Dicrostonyx; Arvicolinae). Biological Journal of the Linnean Society 74: 171-196.

, H. Henttonen, J. Hantula, and H. A. Gubanyi. 2004. Molecular and morphological evidence for multiple species within Paranoplocephala omphalodes (Cestoda, Anoplocephalidae) in Microtus voles (Arvicolinae). Zoologica Scripta 33: $277-$ 290.
Helldin, J. O. 1999. Diet, body condition, and reproduction of Eurasian pine martens Martes martes during cycles in microtine density. Ecography 22: 324-336.

Hoberg, E. P. 2005. Coevolution in marine systems. In Marine parasitology, K. Rohde (ed.). CSIRO Publishing, Collingwood, Australia, p. 327-339.

$\longrightarrow$ K. B. Aubry, AND J. D. BRitTell. 1990. Helminth parasitism in martens (Martes americana) and ermines (Mustela erminea) from Washington, with comments on the distribution of Trichinella spiralis. Journal of Wildlife Diseases 26: 447-452.

- AND D. R. BRooks. 2007. A macroevolutionary mosaic: Episodic host-switching, geographic colonization and diversification in complex host-parasite systems. Journal of Biogeography. (In press.)

, S. J. Kutz, K. E. Galbreath, and J. A. Cook. 2003. Arctic biodiversity: From discovery to faunal baselines-Revealing the history of a dynamic ecosystem. Journal of Parasitology 89: 584595.

, K. J. Monsen, S. Kutz, And M. S. Blouin. 1999. Structure, biodiversity, and historical biogeography of nematode faunas in holarctic ruminants: Morphological and molecular diagnoses for Teladorsagia boreoarcticus $\mathrm{n}$. sp. (Nematoda: Ostertagiinae), a dimorphic cryptic species in muskoxen (Ovibos moschatus). Journal of Parasitology 85: 910-934.

Hornocker, M. G., AND H. S. HASH. 1981. Ecology of the wolverine in northwestern Montana. Canadian Journal of Zoology 59: 12861301.

Ivanov, V. V. 1985. Data on sable ecology in Magadan region. In The mammal ecology of tundra and forest tundra in north-east Siberia, V. G. Krivosheev and F. B. Chernyavsky (eds.). FEB USSR, Vladivostok, Russia, p. 146-153.

JANZEN, D. H. 1985. On ecological fitting. Oikos 45: 308-310.

Jenkins, E. J., G. D. Appleyard, E. P. Hoberg, B. M. Rosenthal, S. J. Kutz, A. M. Veitch, H. M. Schwantje, B. T. Elkin, and L. POLLEY. 2005. Geographic distribution of the muscle-dwelling nematode Parelaphostrongylus odocoilei in North America, using molecular identification of first-stage juveniles. Journal of Parasitology 91: 574-584.

Jennings, D. H., AND W. Threlfall. 1982. Metazoan parasites and food of short-tailed weasels and mink in Newfoundland, Canada. Canadian Journal of Zoology 60: 180-183.

Karmanova, E. M. 1963. Development of Soboliphyme baturini Petrow, 1930 (Nematoda: Dioctophymata) in the body of an intermediate host. In Gel'minty Cheloveka, Zhivotnykh, Rastenii I Bor'ba. S Nimi, k 85-Letiyu Akad, K. I. Skryabina (ed.). AN SSSR, Izd-vo, Russia, p. 241-243.

. 1986. Dioctophymidea of animals and man and diseases caused by them. Fundamentals of nematology, vol. 20. Amerind Publishing Company Private, Limited, New York, New York, 383 p.

KarpenKo, S. V. 1985. Shrew Sorex daphaenodon as paratenic hosts of nematodes Soboliphyme baturini Petrow, 1930. Proceedings of the Siberian Branch of Russian Academy of Science. Biological Series 3: $73-76$.

— A. I. Chechulin, AND A. V. Udaloi. 1998. Clethrionomys rufocanus Sundevall as paratenic hosts of nematodes Soboliphyme baturini Petrow, 1930. The parasites in the nature ecosystems and risk situations. SB RAAS (Siberian Branch of the Russian Academy of Agriculture Sciences), Novosibirsk, Russia, p. 72-75.

- N. E. Dokuchaev, AND E. P. Hoberg. 2007. Nearctic shrews, Sorex spp., as paratenic hosts of Soboliphyme baturini (Nematoda: Soboliphymidae). Comparative Parasitology 74: 81-87.

Kaufmann, R., M. Fuchs, And N. GosterXeier. 2002. The soil fauna of an alpine glacier foreland: Colonization and succession. Arctic, Antarctic, and Alpine Research 34: 242-250.

Kethley, J. B., AND D. E. Johnston. 1975. Resources tracking patterns in bird and mammal ectoparasites. Miscellaneous Publications of the Entomological Society of America 9: 231-236.

KoeHLER, A. V. 2006. Systematics, phylogeography, distribution, and lifecycle of Soboliphyme baturini. M.S. Thesis. University of New Mexico, Albuquerque, New Mexico, 90 p.

Koehler, G. M., AND M. G. Hornocker. 1977. Fire effects on marten habitat in the Selway-Bitterroot Wilderness. Journal of Wildlife Management 41: 500-505. 
Kontrimavichus, V. L. 1962. Epizootiology of soboliphymosis of martens in Khabarov territory. Trudy GELAN 12: $37-42$.

- 1985. Helminths of mustelids and trends in their evolution. Amerind Publishing Company, New Delhi, India, 607 p.

, S. L. Delyamure, and S. N. Boev. 1985. Metastrongyloids of domestic and wild animals. Fundamentals of Nematology, vol. 26. English Translation of Osnovy Nematodologii, Tom. XXVI, Metastrongiloidei Domashnikh I Dikikh Zhivotnykh, Nauka Publishers, Moscow. Oxonian Press Pvt. Ltd., New Delhi, India, 298 p.

Koubek, P., V. Barus, AND B. KoubKovÁ. 2004. Presence of Skrjabingylus petrowi (Nematoda) in central Europe. Parasitology Research 94: 301-303.

Lensink, C. J., R. O. SKoog, AND J. L. Buckley. 1955. Food habits of marten in interior Alaska and their significance. Journal of Wildlife Management 19: 364-367.

Marshall, W. H. 1946. Winter food habits of the pine marten in Montana. Journal of Mammalogy 27: 83-84.

McKeand, J. B. 1998. Molecular diagnosis of parasitic nematodes. Parasitology 117: S87-S96.

Meyer, M. C., AND B. G. Chitwood. 1951. Helminths from fisher (Martes p. pennanti) in Maine. Journal of Parasitology 37: 320-321.

MonaKHov, V. G. 2001. Phenetic analysis of aboriginal and introduced populations of sable (Martes zibellina) in Russia. Russian Journal of Genetics 37: 1074-1081.

Morgan, B. B. 1943. New host records of nematodes from Mustelidae (Carnivora). Journal of Parasitology 29: 158-159.

MurIE, A. 1961. Some food habits of the marten. Journal of Mammalogy 42: $516-521$.

NADLER, S. A. 2002. Species delimitation and nematode biodiversity: Phylogenies rule. Nematology 4: 615-625.

Nagorsen, D. W., R. W. Campbell, and G. R. Giannico. 1991. Winter food habits of marten, Martes americana, on the Queen Charlotte Islands. Canadian Field-Naturalist 105: 55-59.

- M. HAMES, AND W. AdAMs. 1996. Opossums, shrews and moles of British Columbia. University of British Columbia Press, Vancouver, British Columbia, Canada, 149 p.

- K. F. Morrison, AND J. E. Forsberg. 1989. Winter diet of Vancouver Island marten (Martes americana). Canadian Journal of Zoology 67: 1394-1400.

O'Connor, F. B. 1967. The Enchytraeidae. In Soil biology, A. Burges, and F. Raw (eds.). Academic Press Inc., London, U.K., p. 213-257.

Petrov, A. M. 1930. Zur Characteristic des Nematiden aus Komtschatkaer Zobeln Soboliphyme baturini nov. gen. Nov. sp., Zoologischer Anzeiger 86: 9-10, 265-271.

Poole, B. C., K. Chadee, And T. A. Dick. 1983. Helminth parasites of pine marten; Martes americana (Turton), from Manitoba, Canada. Journal of Wildlife Diseases 19: 10-13.

Poulin, R. 1998. Evolutionary ecology of parasites: From individuals to communities. Chapman and Hall, London, U.K., 212 p.

PRICE, E. W. 1930. The occurrence of Soboliphyme baturini Petrow in North America. Journal of Parasitology 17: 57.

Putman, R. J. 2000. Diet of pine martens Martes martes L. in west Scotland. Journal of Natural History 34: 793-797.

Quick, H. F. 1955. Food habits of marten (Martes americana) in northern British Columbia. The Canadian Field-Naturalist 69: 144-147.

RAINE, R. M. 1987. Winter food habits and foraging behaviour of fishers (Martes pennanti) and martens (Martes americana) in Southeastern Manitoba. Canadian Journal of Zoology 65: 745-747.

RausCH, R. L. 1959. Studies on the helminth fauna of Alaska. XXXVI. Parasites of the wolverine, Gulo gulo L., with observations on the biology of Taenia twitchelli Schwartz, 1924. Journal of Parasitology 45: 465-484.

, F. H. FAy, and F. S. L. Williamson. 1990. The ecology of Echinococcus mutilocularis (Cestoda: Taeniidae) on St. Lawrence Island, Alaska. II: Helminth populations in the definitive host. Annales de Parasitologie Humaine et Comparee 65: 131-140.

RoBerTS, L. S., AND J. JANOVY, JR. 2005. Foundations of parasitology, 7th ed. McGraw-Hill Higher Education, Dubuque, Iowa, 702 p.

RonQuist, F., AND J. P. HuelsenBeCK. 2003. MrBayes 3: Bayesian phylogenetic inference under mixed models. Bioinformatics 19: 15721574.

Rozen, S., AND H. SKaletsky. 2000. Primer3 on the WWW for general users and for biologist programmers. In Bioinformatics methods and protocols: Methods in molecular biology, S. Krawetz, and S. Misener (eds.). Humana Press, Totowa, New Jersey, p. 365-386.

Rusin, L. Y., V. V. Aleshin, A. V. Tchesunov, and G. I. Atrashrevich. 2003. The 18S ribosomal RNA gene of Soboliphyme baturini Petrow, 1930 (Nematoda: Dioctophymida) and its implications for phylogenetic relationships within Dorylaimia. Nematology 5: 615628

Sato, H., T. Inaba, Y. Ihama, and H. Kamiya. 1999. Parasitological survey on wild carnivores in north-western Tohoku, Japan. Journal of Veterinary Medical Science 61: 1023-1026.

Schmidt, G. D., AND J. M. Kinsella. 1965. Contribution to the morphology of Soboliphyme baturini Petrow, 1930 (Dictophymoidea: Nematoda). Transactions of the American Microscopical Society 84: 413-415.

ShimaKuRA, K., AND K. OdaJima. 1934. Soboliphyme sahalinensis n. sp. (Nematodes) from Martes zibellina sahalinensis Ognew, Proceedings of the Imperial Academy. Tokoyo 10: 187-190.

Small, M. P., K. D. Stone, And J. A. Cook. 2003. American marten (Martes americana) population structure across a landscape fragmented in time and space. Molecular Ecology 12: 89-103.

SoutiERE, E. C. 1979. Effects of timber harvesting on marten in Maine. Journal of Wildlife Management 43: 850-860.

SwartZ, L. G. 1968. A new natural definitive host, and morphometry of Soboliphyme baturini Petrow, 1930 in interior Alaska. Canadian Journal of Zoology 46: 691-693.

SwoFford, D. L. 2002. PAUP*. Phylogenetic Analysis Using Parsimony (*and Other Methods). Version 4. Sinauer Associates, Sunderland, Massachusetts.

Thompson, I. D., AND P. W. Colgan. 1987. Numerical responses of martens to a food shortage in northcentral Ontario. Journal of Wildlife Management 51: 824-835.

Tran, A. T. T. 2003. The unusual Romanomermis culicivorax mitochondrial genome: Gene order and phylogenetic considerations. M.S. Thesis. University of California, Riverside, California, $111 \mathrm{p}$.

WeCKWerth, R. P., AND V. D. Hawley. 1962. Marten food habits and population fluctuations in Montana. Journal of Wildlife Management 26: 55-74.

WiLson, D. E., AND D. M. REEDER. 2005. Mammal species of the world a taxonomic and geographic reference, 3rd ed. The Johns Hopkins University Press, Baltimore, Maryland, 2,142 p.

Zarnke, R. L., J. S. Whitman, R. W. Flynn, and J. M. Ver Hoef, 2004. Prevalence of Soboliphyme baturini in marten (Martes americana) populations from three regions of Alaska, 1990-1998. Journal of Wildlife Diseases 40: 452-455.

ZiELINSKI, W. J., AND N. P. DunCAN. 2004. Diets of sympatric populations of American martens (Martes americana) and fishers (Marte pennanti) in California. Journal of Mammalogy 85: 470-477.

W. D. SPENCER, AND R. H. BARRETT. 1983. Relationship between food habits and activity patterns of pine martens. Journal of Mammalogy 64: 387-396. 


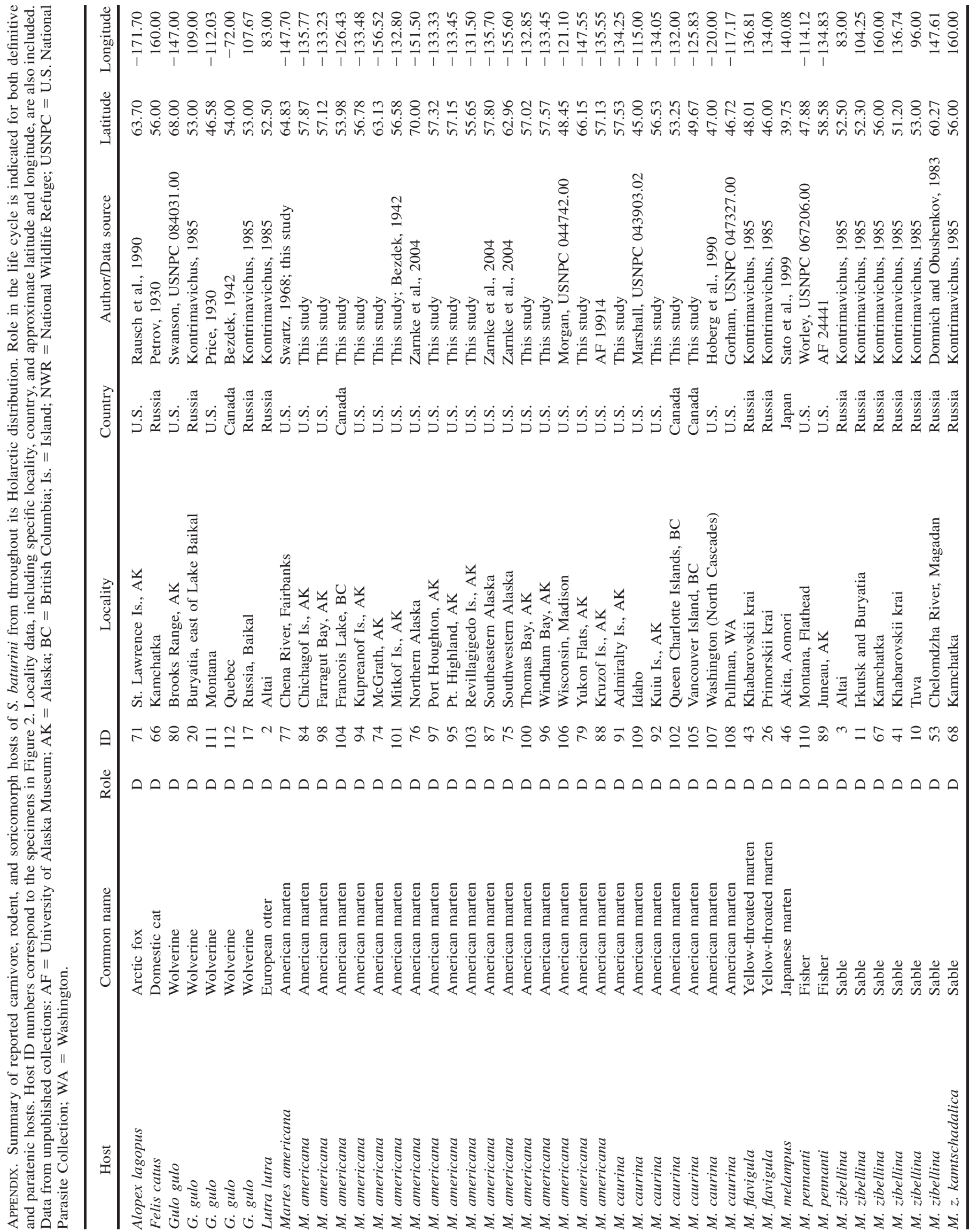




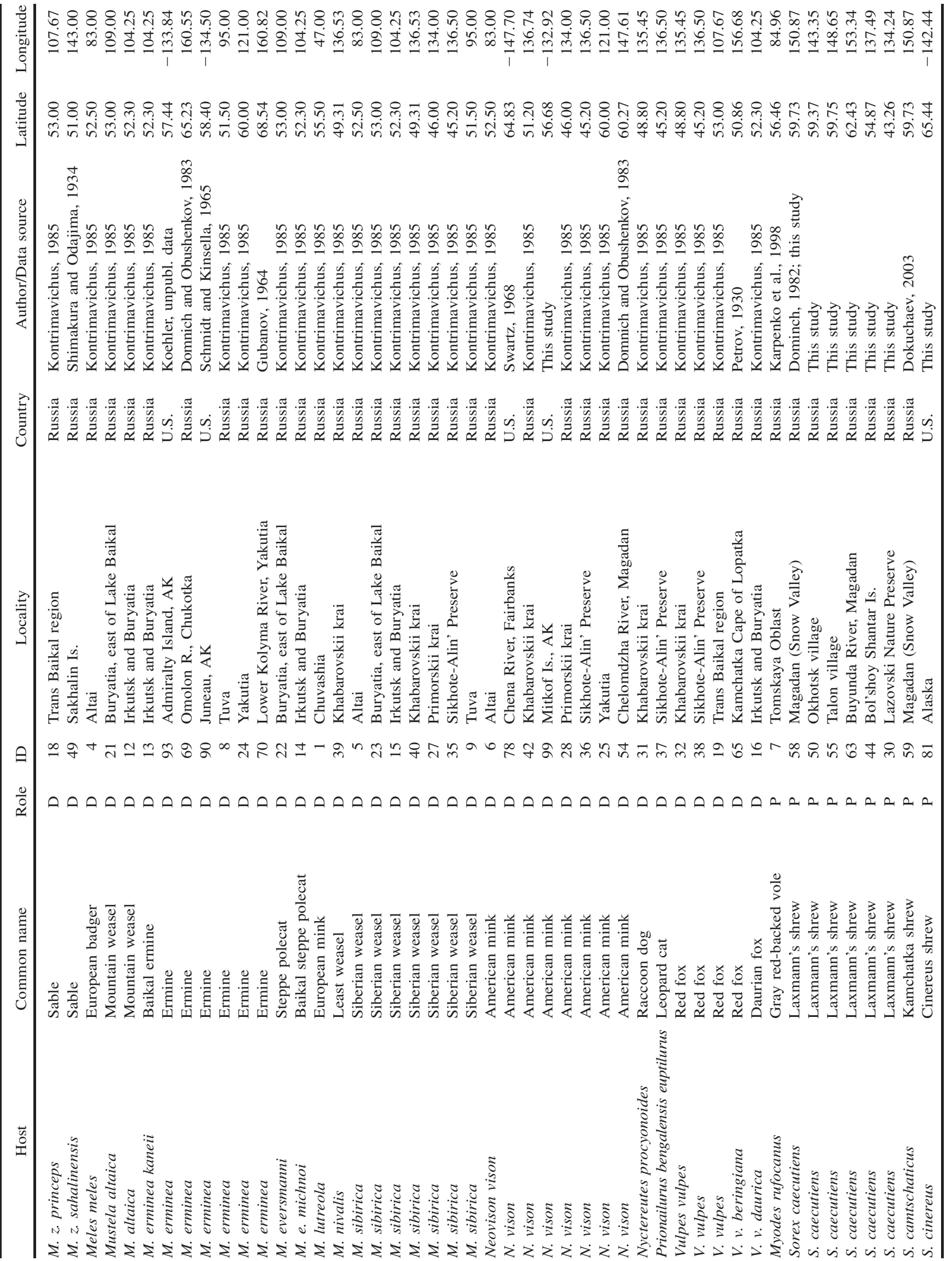




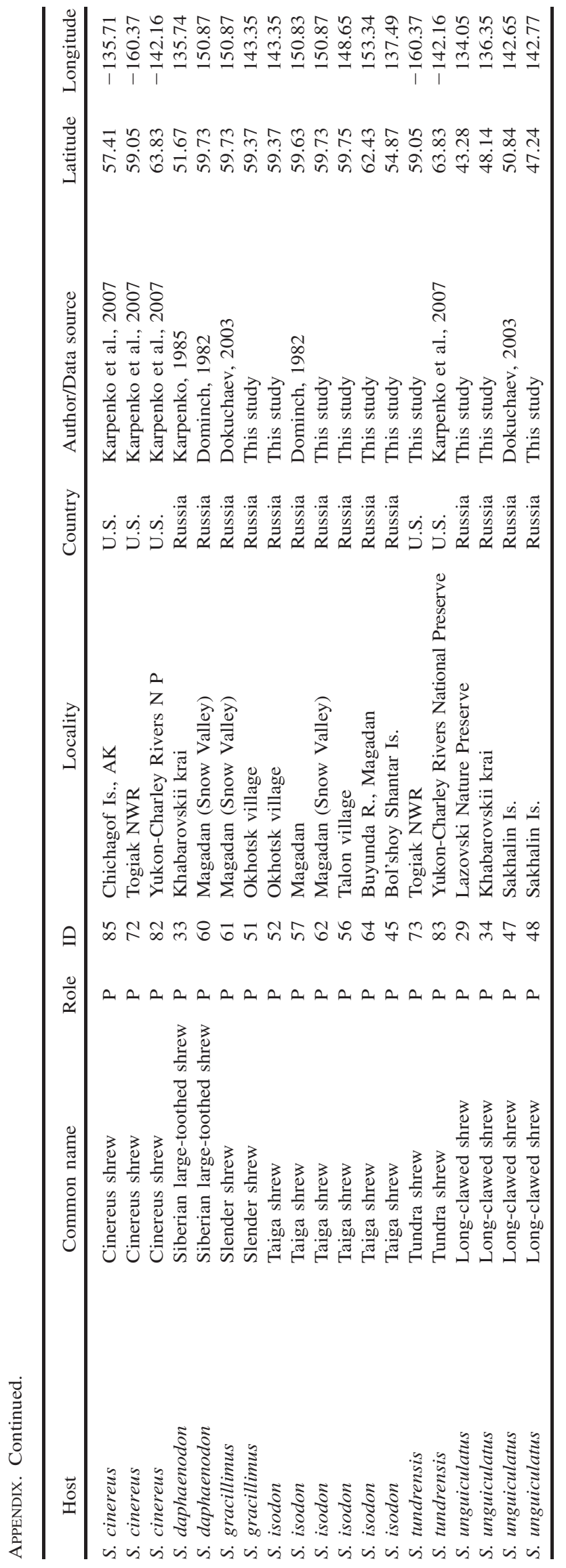

